\title{
Climate diagnostics of the extreme floods in Peru during early 2017
}

\author{
Rackhun Son ${ }^{1} \cdot$ S.-Y. Simon Wang ${ }^{2} \cdot$ Wan-Ling Tseng ${ }^{3} \cdot$ Christian W. Barreto Schuler $^{4} \cdot$ Emily Becker $^{5} \cdot$ Jin-Ho Yoon $^{1}$ (D)
}

Received: 12 March 2019 / Accepted: 29 October 2019 / Published online: 24 December 2019

(c) The Author(s) 2019

\begin{abstract}
From January through March 2017, a series of extreme precipitation events occurred in coastal Peru, causing severe floods with hundreds of human casualties and billions of dollars in economic losses. The extreme precipitation was a result of unusually strong recurrent patterns of atmospheric and oceanic conditions, including extremely warm coastal sea surface temperatures (SST) and weakened trade winds. These climatic features and their causal relationship with the Peruvian precipitation were examined. Diagnostic analysis and model experiments suggest that an atmospheric forcing in early 2017, which was moderately linked to the Trans-Niño Index (TNI), initiated the local SST warming along coastal Peru that later expanded to the equator. In January 2017, soil moisture was increased by an unusual expansion of Amazonian rainfall. By March, localized and robust SST warming provided positive feedback to the weakening of the trade winds, leading to increased onshore wind and a subsequent enhancement in rainfall. The analysis points to a tendency towards more frequent and stronger variations in the water vapor flux convergence along the equator, which is associated with the increased precipitation in coastal Peru.
\end{abstract}

\section{Introduction}

In early 2017, coastal northeast Peru experienced a series of devastating floods. Sustained downpours began in January 2017 and caused severe river floods and landslides, killing 114 people and displacing 184,000 people (USAID, ${ }^{1}$ 24 April 2017). Economic losses exceeded $\$ 3$ billion USD (The Guardian, ${ }^{2} 13$ April 2017). The flooded coastal area, where more than 5000 people were affected (Fig. 1a), is

Electronic supplementary material The online version of this article (https://doi.org/10.1007/s00382-019-05038-y) contains supplementary material, which is available to authorized users.

Jin-Ho Yoon

yjinho@gist.ac.kr

1 School of Earth Sciences and Environmental Engineering, Gwangju Institute of Science and Technology, 123 Cheomdangwagi-ro, Buk-gu, Gwangju 61005, South Korea

2 Department of Plans, Soils, and Climate, Utah State University, Logan, UT, USA

3 Research Center for Environmental Changes, Academia Sinica, Taipei, Taiwan

4 Dirección de Meteorología y Evaluación Ambiental Atmosférica, Servicio Nacional de Meteorología e Hidrología (SENAMHI), Lima, Peru

5 University of Miami Rosenstiel School of Marine and Atmospheric Sciences, Miami, FL, USA climatologically semi-arid, with an average annual precipitation of $100 \mathrm{~mm}$. However, the first 3 months of 2017 showed abnormal precipitation (Fig. 1b), with some regions receiving 10 times the average rainfall; a weather station in El Partidor, located on the northeast coast, recorded a maximum rainfall of $258.2 \mathrm{~mm}$ within $24 \mathrm{~h}$ in early March (Fig. S1b) (ENFEN 2017c; Servicio Nacional de Meteorologia del Peru, ${ }^{3} 4$ April 2017). Early 2017 saw neutral El Niño-Southern Oscillation (ENSO) conditions (IRI, ${ }^{4} 16$ February 2017), yet sea surface temperature (SST) off the Peruvian coastline was abnormally high, leading to a so-called 'coastal El Niño' (Nature News, ${ }^{5} 25$ April 2017; Garreaud 2018), as in the past 1925 case (Takahashi and Martínez 2017).

Excessive precipitation in northeast Peru is controlled by two dominant mechanisms: the southward migration of the Inter Tropical Convergence Zone (ITCZ) and the westward displacement of monsoonal convection crossing the Western Andes (Lagos and Buizer 1992). Abnormally warm SST

\footnotetext{
${ }_{1}$ Peru-Floods Fact Sheet \#2 (https://www.usaid.gov/sites/default/files /documents/1866/peru_fl_fs02_04-24-2017.pdf).

2 https://www.theguardian.com/global-development-professionalsnetwork/2017/apr/13/peru-prevent-floods-landslides-climate-change.

${ }^{3}$ Monitoreo de lluvias en el norte Enero-Febrero-Marzo 2017 (https ://public.wmo.int/es/media/noticias-de-los-miembros/monitoreo-delluvias-en-el-norte-enero-febrero-\%E2\%80\%93-marzo-2017).

${ }^{4}$ IRI ENSO Forecast (https://iri.columbia.edu/our-expertise/climate/ forecasts/enso/2017-february-quick-look/).

5 https://www.nature.com/news/surprise-el-ni\%C3\%B1o-cause s-devastation-but-offers-lessons-for-ecologists-1.21891.
} 
(a)

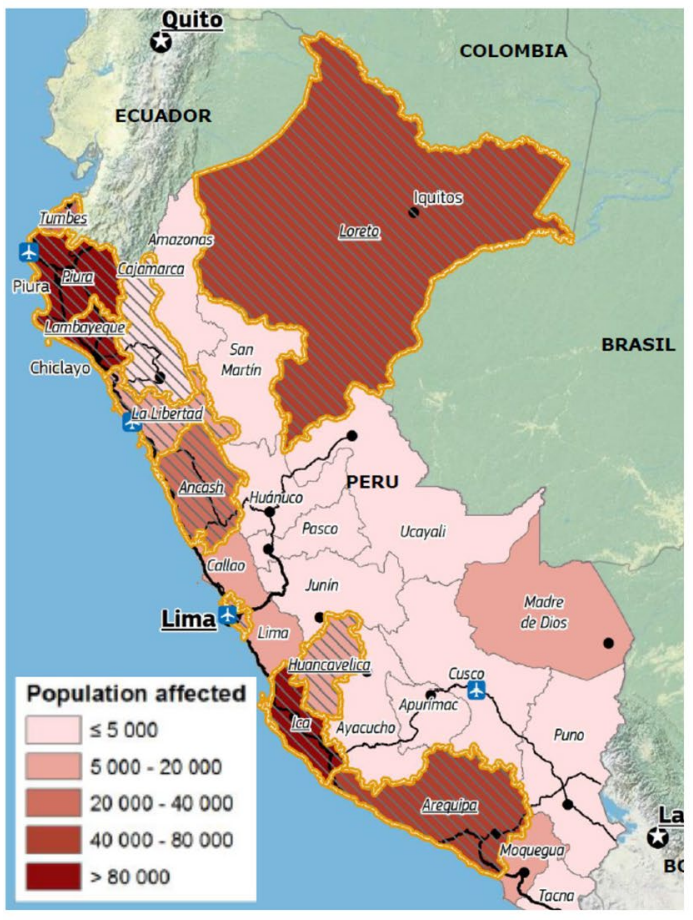

Fig. 1 a Peru floods. Situation overview 23 March 2017 (ERCC, https://reliefweb.int/map/peru/peru-floods-situation-overview-dgecho-daily-map-23032017). b Anomalies of 3-months averaged pre-

in the eastern tropical Pacific can enhance convective systems and increase rainfall in coastal Peru (Sulca et al. 2017; Woodman 1999). During major El Niño events higher than average rainfall is expected, and previous studies have linked strong El Niño years to historic floods, such as 1982-1983 and 1997-1998 (Coelho 2002; Goldberg et al. 1987; Takahashi 2004; Lavado-Casimiro and Espinoza 2014). Takahashi and Martínez (2017) showed a local SST influence on Peru's rainfall, as shallow warm SST anomalies in the eastern Pacific can strengthen the ITCZ south of the equator. Other atmospheric and SST conditions that have coexisted with Peruvian floods include upper-level westerly wind anomalies over northern Peru (Takahashi 2004; Sulca et al. 2017) and strong surface convergence, both of which accompany the interannual variability of the eastern Pacific ITCZ (Yu and Zhang 2018). Lower tropospheric convergence, which is modulated by SST gradients in the eastern Pacific, also can increase precipitation (Back and Bretherton 2009).

For reasons disclosed in the ensuing analysis, the early 2017 floods in Peru were not accompanied by many of the aforementioned atmospheric and oceanic conditions, which inspired us to pursue further exploration. This level of ambiguity in climate forcing compounded the low skill in seasonal forecasting, which hampered decision making (b)

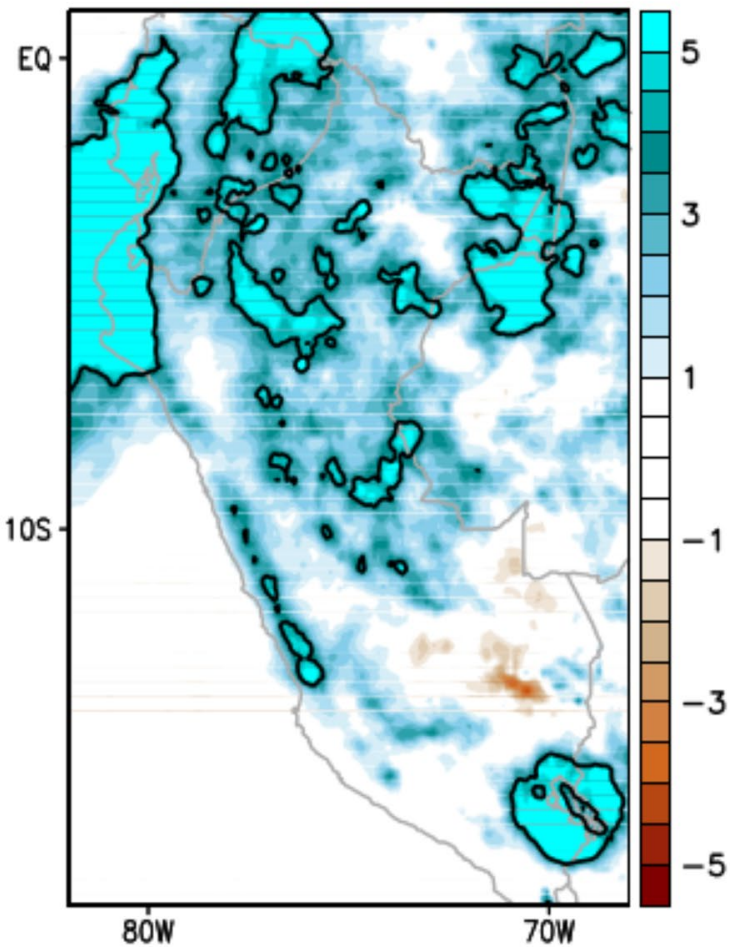

cipitation (mm/day, GSMaP) from January to March 2017 (black contour line is for $4 \mathrm{~mm} /$ day of anomailes)

(Ramirez and Briones 2017). The objective of this study is to diagnose the Peru floods of 2017 and to examine the possible large-scale forcing. Section 2 describes the data and methods. Section 3 examines synoptic processes and investigates the recurrent climatic features associated with this event. Additionally, we utilize model simulations to look at the forcing and projections about future climatic conditions. The last section provides some concluding remarks.

\section{Data and methodology}

\subsection{Data}

To characterize the 2017 event, we use station records over the National Service of Meteorology and Hydrology of Peru and daily land precipitation from the Climate Prediction Center (CPC)-Global Unified Gauge-Based Analysis (resolution of $0.5^{\circ} \times 0.5^{\circ}$ ), from 1979 to 2017 (Chen et al. 2008). For the oceans, we use daily precipitation from Global Satellite Mapping of Precipitation (GSMaP) with a resolution of $0.25^{\circ} \times 0.25^{\circ}$, from 2008 to 2017 (Okamoto et al. 2005). For model evaluation, we also use monthly precipitation from Global Precipitation Climatology Project (GPCP V2.3), with 
Table 1 Description of ECHAM5 experiment designs

\begin{tabular}{lll}
\hline Experiment & SST & SST anomaly domain \\
\hline CTL & Climatology & None \\
Global & Climatology + global anomaly & Global \\
EP (Eastern Pacific) & Climatology + EP anomaly & $20 S-20 \mathrm{~N}, 160 \mathrm{~W}-80 \mathrm{~W}$ \\
\hline
\end{tabular}

a resolution of $2.5^{\circ} \times 2.5^{\circ}$ since 1979 (Adler et al., 2003). The SST data is obtained from NOAA High-resolution $\left(0.25^{\circ} \times 0.25^{\circ}\right)$ Blended Analysis of Daily SST and Ice and starts in 1981 (OI SST V2; Reynolds et al. 2007). Ocean temperature of 40 vertical layers is taken from the Global Ocean Data Assimilation System (GODAS), with a resolution of $1.0^{\circ} \times 1 / 3^{\circ}$, starting in 1980 (Behringer and Xue 2004). The daily surface winds and soil wetness are derived from the Japanese 55-year Reanalysis (JRA55) with a resolution of $1.25^{\circ} \times 1.25^{\circ}$, available $1958-2017$ (Kobayashi et al. 2015). JRA55 has 27 vertical levels, from 1000 to $10 \mathrm{mb}$; we integrated water vapor flux up to $300 \mathrm{mb}$. For consistency, all anomalies are calculated using the common period 1979-2017, except GODAS from 1980, OI SST from 1981 and GSMaP from 2000. Major climate indices are provided by the NOAA Earth System Research Laboratory (https:// www.esrl.noaa.gov/psd/data/climateindices/list/).

\subsection{Water vapor budget}

Generally, heavy precipitation is supplied by the pooling of atmospheric moisture through surface evaporation, atmospheric moisture transport and convergence (Trenberth et al. 2003). In the tropics, the maintenance of water vapor is predominantly controlled by large-scale transport (Chen 1985). Here, we apply atmospheric water vapor budget analysis to understand precipitation maintenance in northern Peru and the eastern tropical Pacific. The moisture flux $(\vec{Q})$ is divided into divergent and rotational terms $\left(\vec{Q}=\vec{Q}_{D}+\vec{Q}_{R}\right)$, where $\overrightarrow{Q_{D}}$ is the divergent term and $\vec{Q}_{R}$ is the rotational term. Since the divergence of moisture flux is theoretically independent from the rotational component $\left(\vec{Q}_{R}\right)$, we only consider the divergent component $\left(\vec{Q}_{D}\right)$. Vertically-integrated water vapor flux $(\vec{Q})$ and potential function of the water vapor flux $\left(\chi_{Q}\right)$ are computed as follows:

$\vec{Q}=\frac{1}{g} \int_{p_{T}}^{p_{s}} \vec{V} q \cdot d p$

$\nabla^{2} \chi_{Q}=\nabla \cdot \overrightarrow{Q_{D}}=\nabla \cdot \vec{Q}$

where $g$ is the gravitational acceleration, $\vec{V}$ is wind vector, $q$ is specific humidity, $p_{s}$ is surface pressure and $p_{T}$ is pressure at the top of the atmosphere, considered to be $300 \mathrm{mb}$
(Peixoto and Oort 1992). The Andes are remarkably elevated mountains, so a correction has to be made by removing the topographic effect from Eq. (1), taking the reduction of surface pressure up to $500 \mathrm{hPa}$.

\subsection{Numerical simulations}

To diagnose the effect of remote forcing, we use the ECHAM5.4 model (Roeckner 2003) to simulate the 2017 event with basin-specific SST conditions. ECHAM5 is the 5 th generation of the ECHAM general circulation model, a spectral atmosphere model developed at the Max Planck Institute for Meteorology (MPI). Spatial resolution here is T63 with 31 vertical layers topping at $10 \mathrm{hPa}(\sim 30 \mathrm{~km})$. Physics schemes include the Nordeng cumulus convective scheme (Nordeng 1994), an improved version of the Tiedtke mass flux scheme (Tiedtke 1989).

A series of numerical experiments are designed to test the impacts of different basin SST forcing on the eastern Pacific. Also the patterns of winds and precipitation are compared with the 2017 observations. The HadISST data (Rayner et al. 2003 ) is used as the lower boundary condition. Six experiments are conducted with different SST settings, namely the control run (CTL), Global SST forcing, western Pacific (WP) forcing, Atlantic Ocean (AT), WP + AT forcing, and eastern Pacific (EP) forcing; explanation and domain boundary of these experiments are shown in Table 1. The CTL experiment is forced with the climatological monthly SST (1960-2017), while the rest of the experiments are forced by the observed monthly SST in the designated regions and climatological monthly SST elsewhere. Each experiment runs from July 2016 to March 2017 with 10 members. The experiments are initiated with a few days of results from the first ensemble member in order to remove the effects of the model's internal variability, thereby prioritizing the SST forcing.

\section{Results}

\subsection{Synoptic evolution of the 2017 event}

Figure 2 shows the hydrological evolution of floods in the northern coast of Peru, which includes Piura, the most affected province (Fig. 1; $95 \mathrm{~W}-78.75 \mathrm{~W}, 9 \mathrm{~S}-3 \mathrm{~S}$, black box in Fig. 6c), showing a series of heavy rain episodes and 
Fig. 2 From bottom to top, daily underground soil wetness of the top layers (averaged $2 \mathrm{~cm}$ and $1 \mathrm{~m}$ layer, dark blue, $\%$, JRA55), 5 days accumulated land precipitation (dark aqua, $\mathrm{mm} / 5$ days, CPC_UNI), SST (dark red, ${ }^{\circ} \mathrm{C}$, OI_HRD) and (-) V-wind (dark green, $\mathrm{m} / \mathrm{s}$, JRA55). Four episodes of flooding (F0, F1, F2, F3) are indicated by grey shades. Each light colors are for its long term mean and all indices are averaged on the same domain (95 W-78.75 W, 9S-3S)

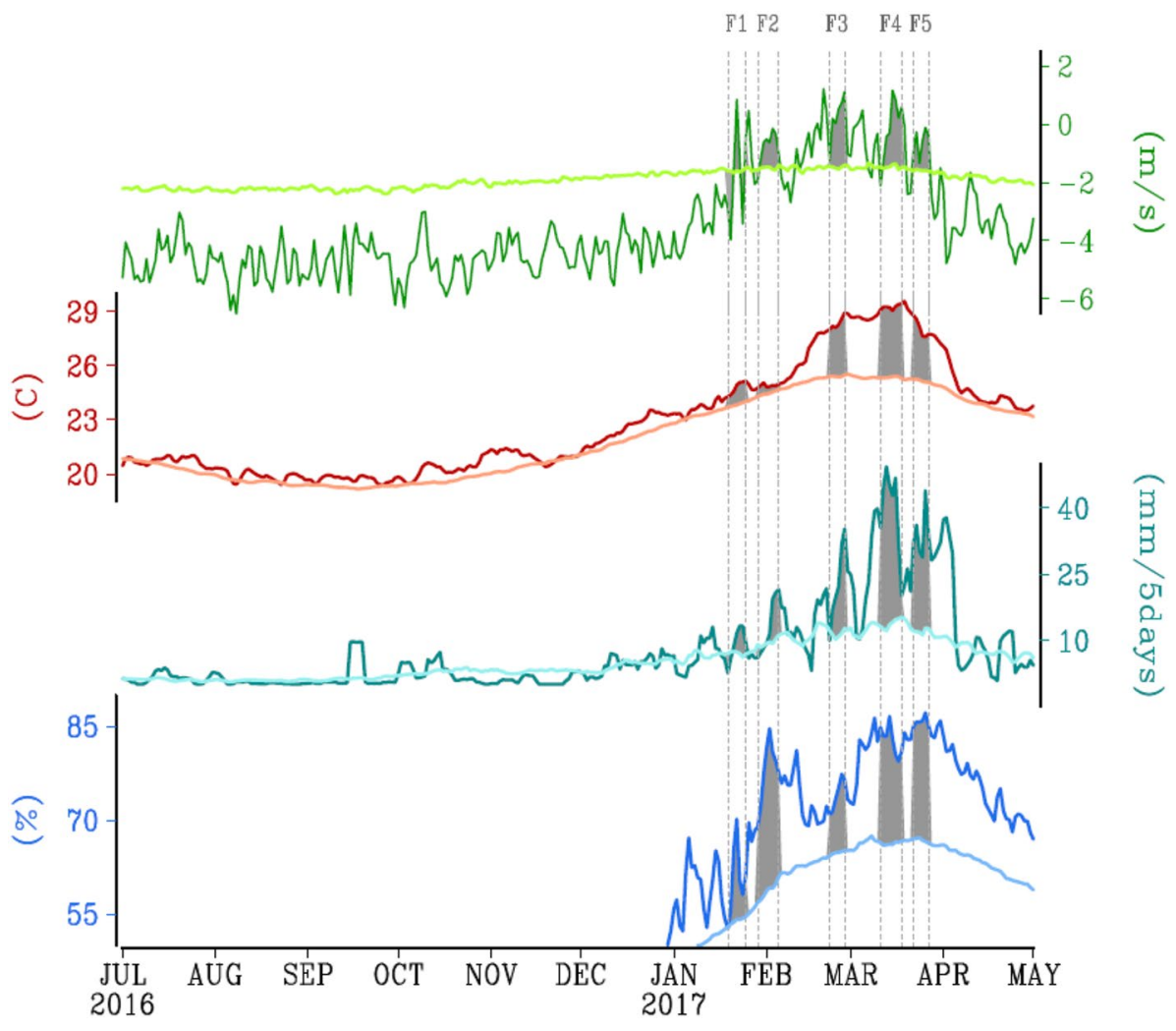

subsequent floods from January to March. The first and second episodes occurred through late January and early February 2017, corresponding to the weakening of the trade winds while considerably increasing the soil moisture (marked as F1 and F2 in Fig. 2). The subsequent downpours through mid-March accompanied only a moderate increase in soil moisture, suggesting that the topsoil layers were close to saturation. This feature arguably contributed to the most severe flooding in March, since the soil could not absorb the excessive rainfall during F4 and F5. Meanwhile, SST increased only slightly in January for F1 and F2, but the change became pronounced during the latter three floods (F3, F4 and F5). Local SST increase is expected after the trade winds near Peru weaken (ENFEN 2017a, b), because the weakened wind stress can reduce coastal upwelling (Huyer et al. 1991; Albert et al. 2010).

The spatial patterns between these heavy rain episodes are displayed in Fig. 3. In January 2017, most of the rainfall in Peru appears to be an extension from the Amazon basin (Fig. 3a), with minimal rainfall along coastal Peru. This rainfall pattern echoes the development of the South American Monsoon System (SAMS), which is characterized by extensive convection developed over the Amazon and occasional expansion across the Andes mountains (Silva and Kousky 2012). At the same time, the weakened trade winds formed in January over the tropical eastern Pacific (Fig. 3d). By February, while the strong northerly wind anomalies intensified (Fig. 3e), an oceanic rainband formed south of the equator (Fig. 3b) and the warmer ocean surface appeared along the Peruvian coast (Fig. 3e). The scale of the rainband expanded in March, reaching northwestern Peru (Fig. 3c). This is consistent with weather station records showing that most heavy rains along the coast occurred in February and March (Fig. S1b-h). Accompanied by the wind anomalies, the local SST warming also intensified further (Fig. 3f). We next computed the cross correlation between surface V-wind and SST anomalies in the same domain as Fig. 2, from December 2016 to March 2017. The cross correlation (Fig. 4) shows that SST responds to negative V-wind within about 5 days ( $r>0.8$ ), suggesting that the coastal SST warming is a result of the weakened trade winds and southward shift of the ITCZ.

Takahashi and Martínez (2017) found that a local warm SST anomaly is linked to Peruvian flooding. While this local warm SST anomaly is sometimes referred to as a "coastal El Niño," the vertical structure of the ocean temperature during 2016-2017 did not resemble typical El Niño years. As shown in Fig. 5, cooling was present in the deep ocean of the western Pacific, and this negative temperature anomaly gradually propagated to the east (Fig. 5a1-4). These processes resemble the declining phases of strong El Niño years (Fig. 5b1-4) rather than the onset phases (Fig. 5c1-4). By contrast, the sudden appearance of coastal warm SST near Peru in early 2017 was shallow and localized (Fig. 5a5), 

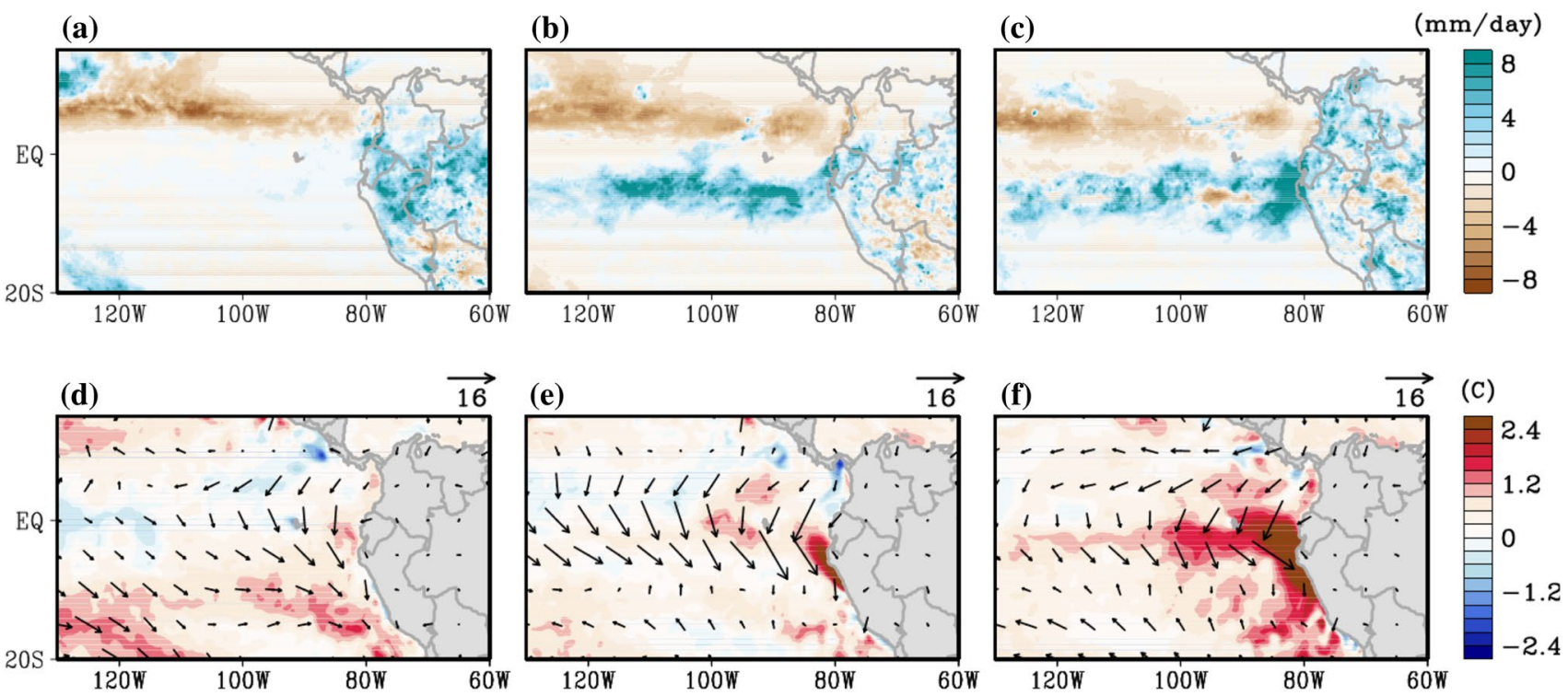

Fig. 3 a-c Anomalies of monthly averaged precipitation (mm/day, GSMaP) from January to March 2017. d-f Anomalies of monthly averaged SST $\left({ }^{\circ} \mathrm{C}\right.$, OI_SST_V2) and surface winds (m/s, JRA55) from January to March 2017

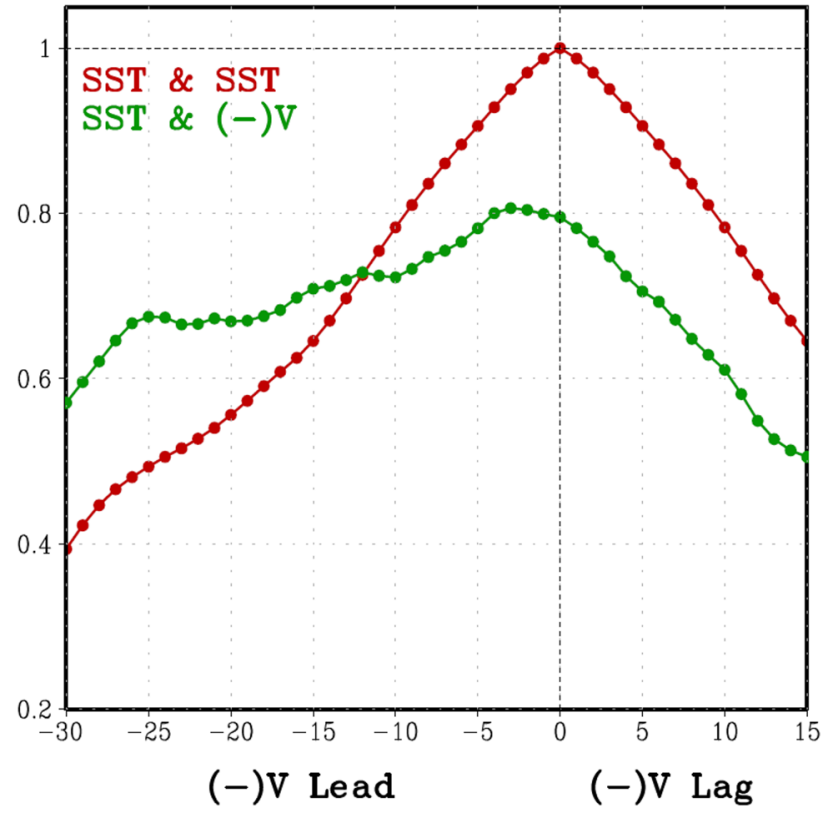

Fig. 4 Cross (lead-lag) correlation of SST and (-) V-wind (green) and SST itself (red) from December 2016 to March 2017. Negative integer (left) on $\mathrm{x}$-axis represents the number of days (-) V-wind leads SST; positive integer (right) is vice versa. All indices are from the same domain $(95 \mathrm{~W}-78.75 \mathrm{~W}, 9 \mathrm{~S}-3 \mathrm{~S})$. All the coefficient values above 0.26 are significant in the level 0.01

without the associated subsurface warming expected during a "normal" El Niño (Fig. 5b1, c4). Therefore, the 2017 event does not appear to be driven by the typical El Niño mechanism and requires further examination.

\subsection{Composite diagnostics}

To examine possible recurring features of the atmospheric and ocean conditions associated with the 2017 event, we conducted composite analysis for precipitation, surface winds, divergence of vertically-integrated water vapor flux $\left(\vec{Q}_{D}\right)$, potential function of the water vapor flux $\left(\chi_{Q}\right)$, and SST during January-March (JFM) from 1979 to 2016. We selected the six highest precipitation years $(1987,1989$, 1993, 2001, 2008, 2012) and six lowest precipitation years $(1982,1985,1988,1990,1995,2004)$ based on the oceanic and Peruvian precipitation, denoted as PP (black box at Fig. 6c; $95 \mathrm{~W}-78.75 \mathrm{~W}, 9 \mathrm{~S}-3 \mathrm{~S})$. To focus on the local SST warming, we exclude the strong El Niño years of 1982-1983 and 1997-1998. The precipitation anomalies and strong northerly wind anomalies in Fig. 6a depict the southwardshifted ITCZ. Correspondingly, the divergent component of water vapor fluxes and potential function of the water vapor flux $\left(\vec{Q}_{D}\right.$ and $\chi_{Q} ;$ Fig. 6b) forms a distinct convergence zone around $5 \mathrm{~S}$, supporting the increased/shifted precipitation band in the tropical eastern Pacific. The local maximum of SST off northwest Peru due to the onshore wind anomaly suppressing coastal upwelling (Fig. 6c) resembles the JFM 2017 situation. We also show the regression coefficients of all these variables with PP in Fig. 6d-f. Consistent patterns are found in all the atmospheric and oceanic variables, suggesting that increased rainfall in northwest Peru is associated with these common atmospheric and oceanic features. 

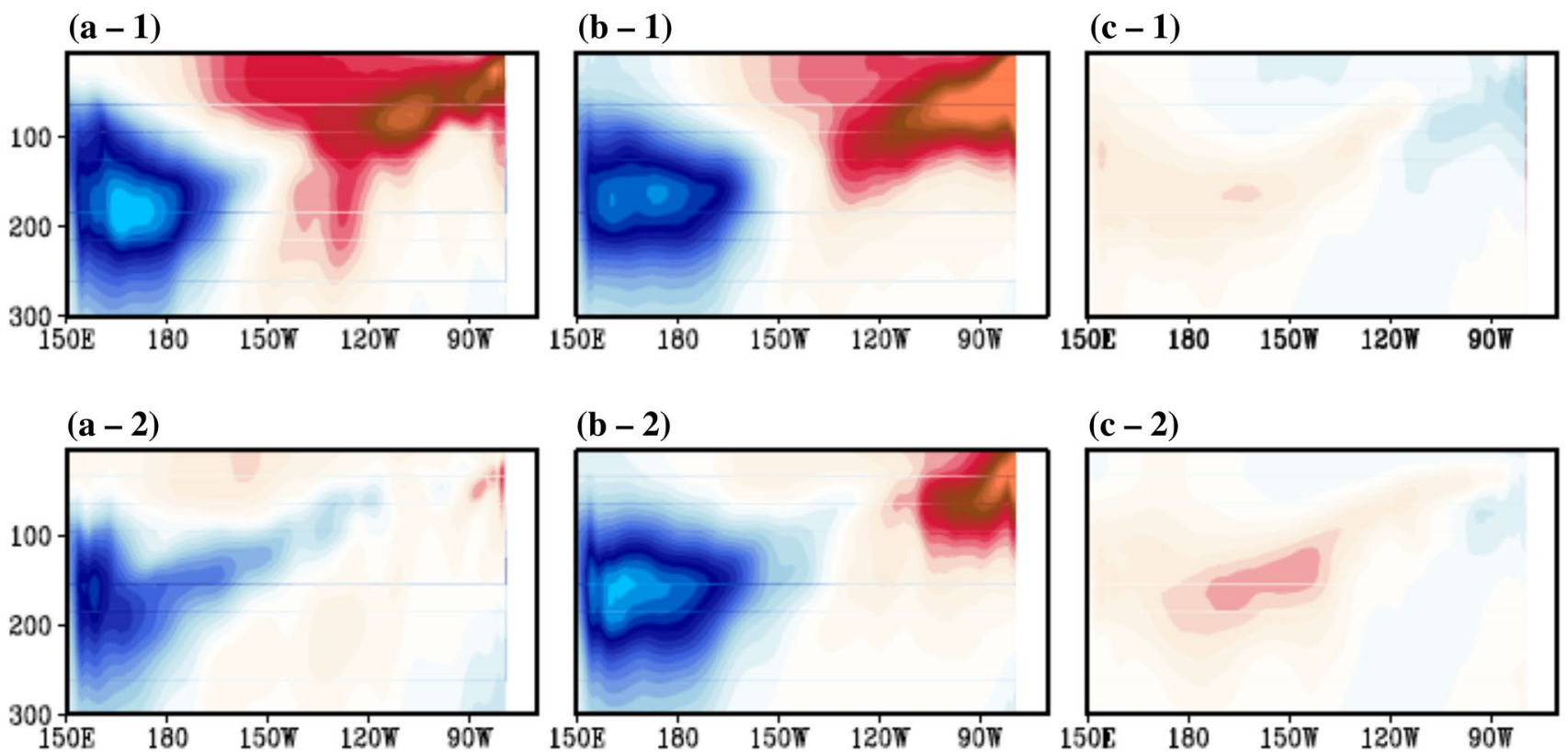

$(\mathbf{c}-2)$

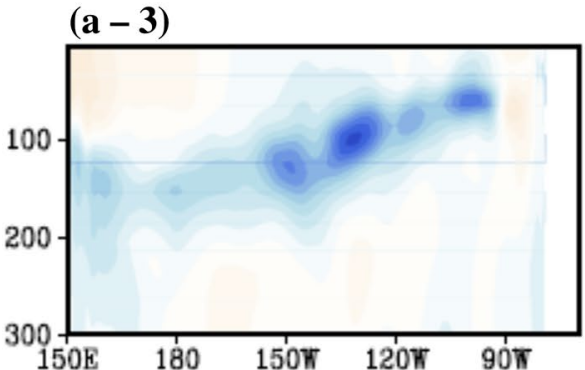

$$
(\mathbf{b}-\mathbf{3})
$$

$$
(\mathbf{c}-3)
$$
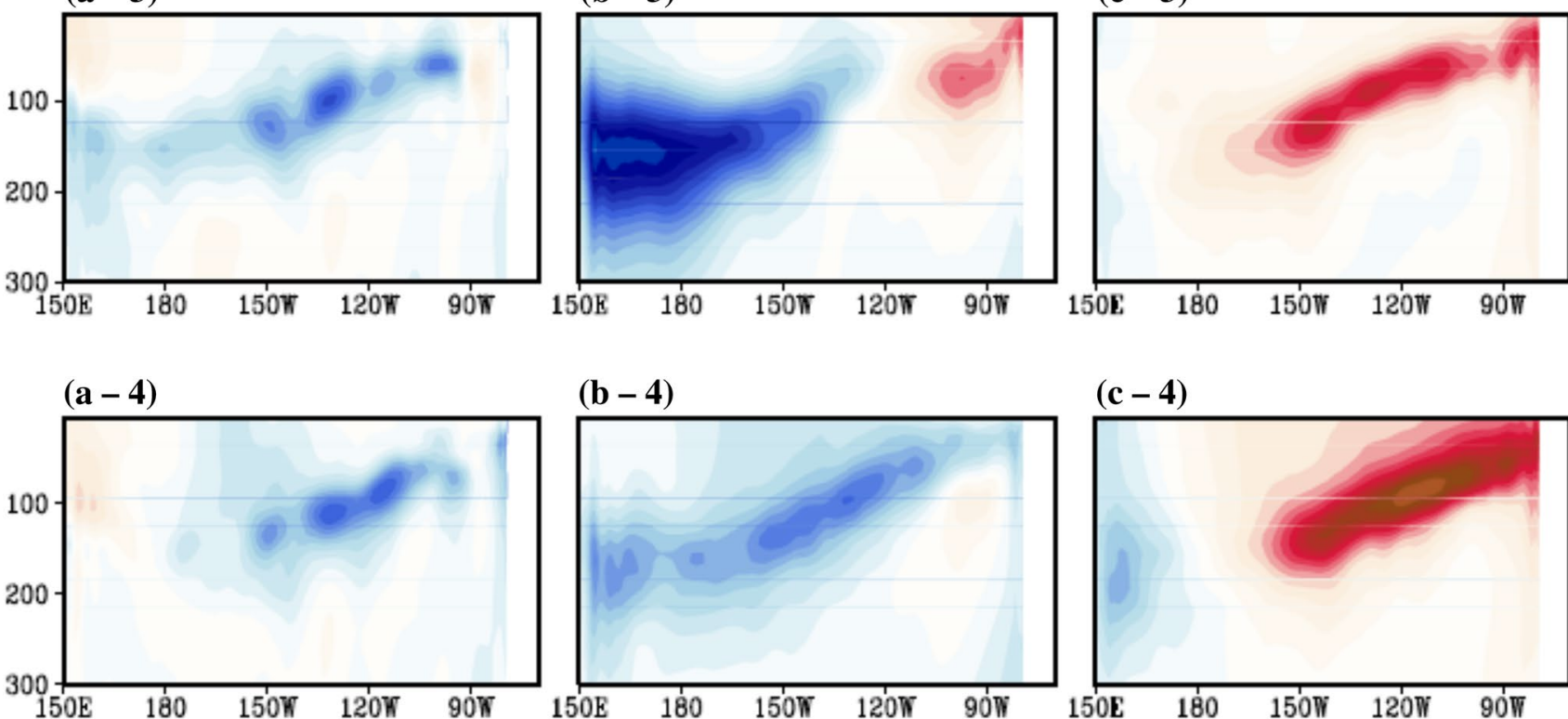

$(\mathbf{b}-4)$

$(\mathbf{c}-4)$
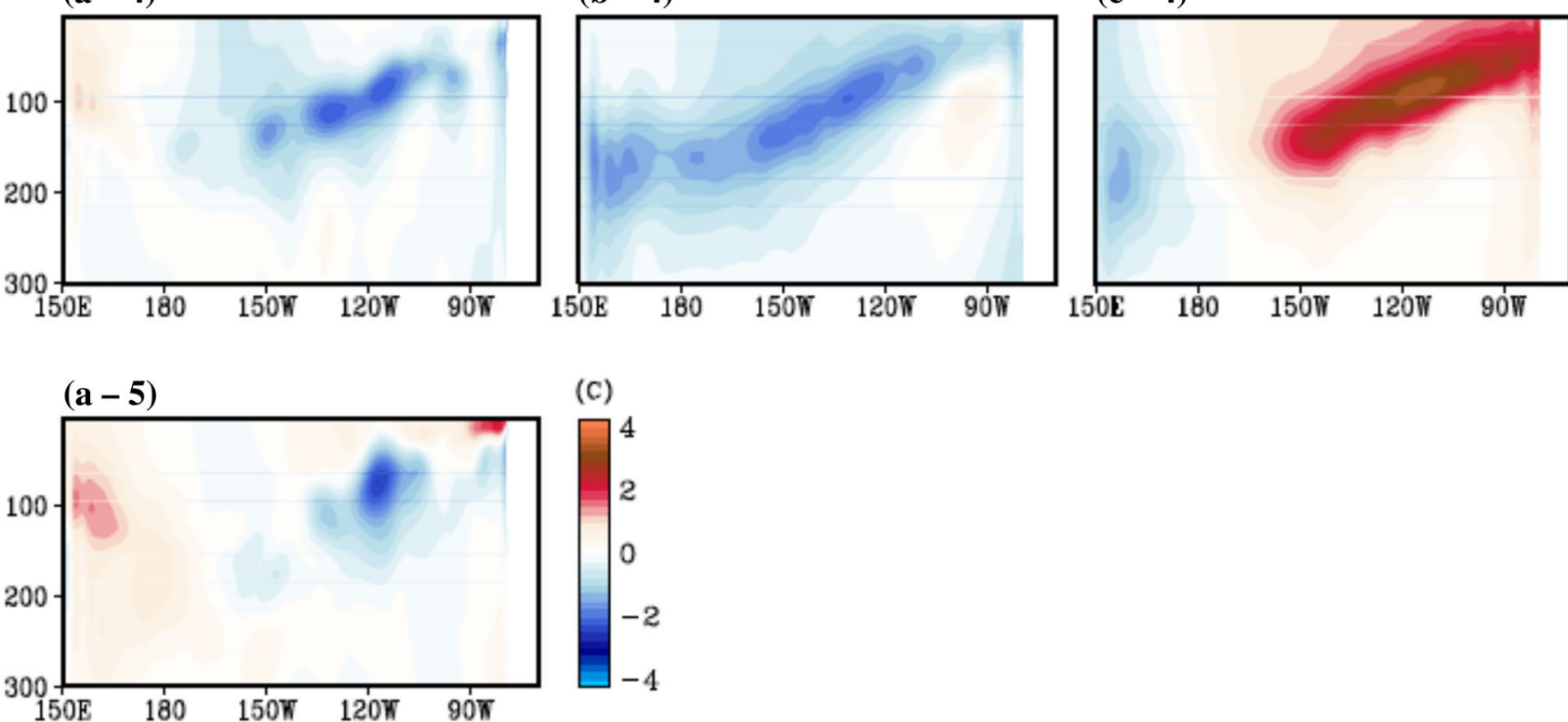

Fig. 5 Four phases (3 months unit) of evolution of latitudinal averaged (10S-EQ) potential ocean temperature anomaly (after 1980, GODAS): a 2016-2017 case (1: JAN-MAR2016, 2: APR-JUN2016, 3: JUL-SEP2016, 4: OCT-DEC2016, 5: JAN-MAR2017), b com- posited declining phases of strong El Niño years (82-83, 87-88, 90-91, 97-98). c composited onset phases of strong El Niño years (added 2015-2016). The five strong El Niño years are classified by Oceanic Niño Index (ONI, http://ggweather.com/enso/oni.htm) 


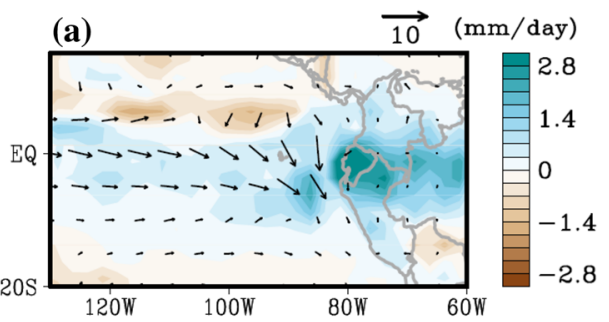

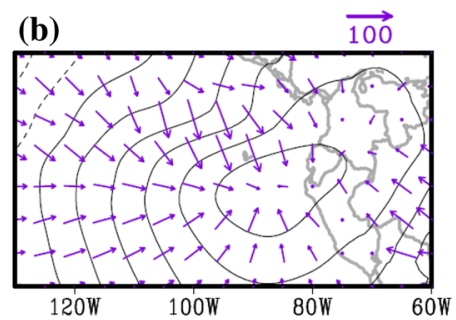

(c)

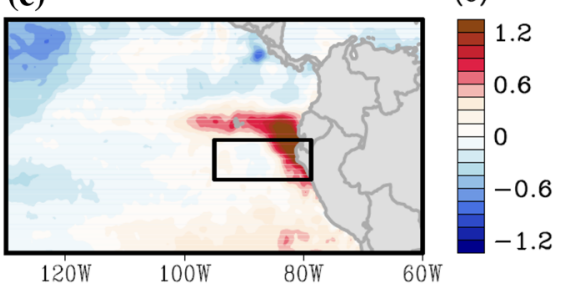

(e)

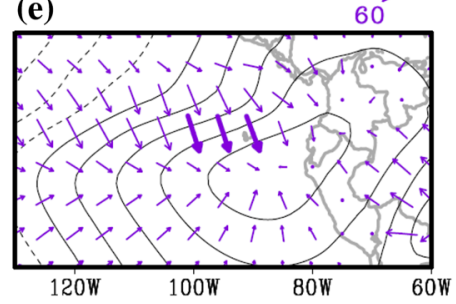

(C)

(f)

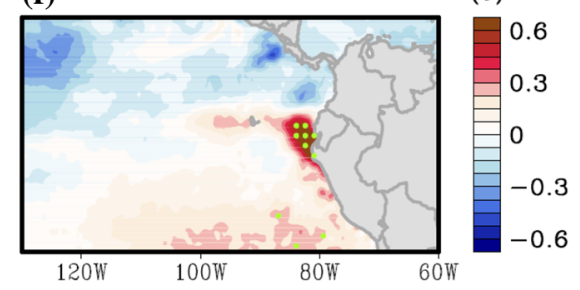

Fig. 6 a-c Composite analysis for $6 \mathrm{max} / \mathrm{min}$ years $\left(\sum \max -\sum \min\right.$ ). a Precipitation (shade, $\mathrm{mm} /$ day) and winds (black vector, $\mathrm{m} / \mathrm{s})$. b Vertically-integrated divergent water vapor flux $\left(Q_{D}\right.$, purple vector, $\mathrm{kg} / \mathrm{m} \mathrm{s}$ ) and potential function of the vapor flux $\left(\chi_{Q}\right.$, contour, interval is $8 \times 10^{-6} \mathrm{~g} \mathrm{~m}^{2} / \mathrm{kg} \mathrm{s}$ ) calculated by regressed $\mathrm{Q}_{\mathrm{D}}$.

By expanding the domain of Fig. 6 (Supplemental Figure S2), the dominant divergence of water vapor flux in terms of $\chi_{Q}$ is found to be centered in the central-western Pacific (around the Dateline); this is consistent among the composite, regression and the 2017 anomalies. Strong divergent moisture fluxes stretch outward and reach the eastern North Pacific and, from there, induce southward fluxes across the equator while pushing the ITCZ southward.

For comparison purposes, we derived a Peruvian SST index (PSST) based on the significance of regression with PP in Fig. 6f (green points, $85 \mathrm{~W}-80 \mathrm{~W}, 5 \mathrm{~S}-\mathrm{EQ}$ ). We then computed the correlation coefficients of PSST with the NOAA climate indices for 1979-2017, which are summarized in Table 2. Contrary to the natural decadal-to-multidecadal variations, such as PDO and AMO, almost all climate indices related to ENSO are correlated significantly $(r>0.37, p<0.01)$ with PSST, given its resemblance to the Niño $1+2$ index (N12; $90 \mathrm{~W}-80 \mathrm{~W}, 10 \mathrm{~S}-\mathrm{EQ})$. By regressing out the Niño3.4 component from PSST (denoted as PSST-N34), most ENSO-related correlations become statistically insignificant $(p>0.01)$, whereas the Trans-Niño Index (TNI), which has been suggested to capture different flavors of ENSO (Trenberth and Stepaniak 2001), increases its correlation with PSST-N34. This result is not surprising, given that TNI is derived from the SST difference between eastern and western tropical Pacific and is orthogonal with Niño3.4. Thus, the early 2017 local SST warming could be a Trans-Niño event.

Further examination of the regression coefficient between TNI and other climate variables (precipitation, winds and c SST (shade, ${ }^{\circ} \mathbf{C}$ ).d-f Regression coefficient map of JFM anomalies based on precipitation of Peru (black box at c): vertically, same variables are used with $(\mathbf{a}-\mathbf{c})$. 0.01 level significant values are marked as thicker arrows (winds and vapor flux) and points (precipitation and SST)

SST; Fig. 7c) shows consistent results with PSST-N34 (Fig. 7a, b), i.e. a distinct increase in precipitation over land. However, the SST regression reveals more distinct negative

Table 2 Correlation with PSST and PSST-N34 during 1979-2017

\begin{tabular}{lrr}
\hline & PSST & PSST-N34 \\
\hline Niño 3.4 (N34) & $\mathbf{0 . 5 1}$ & -0.02 \\
Niño 1 + 2 (N12) & $\mathbf{0 . 9 4}$ & $\mathbf{0 . 6 8}$ \\
Trans-Niño Index (TNI) & $\mathbf{0 . 4 3}$ & $\mathbf{0 . 7 4}$ \\
Western Hemisphere Warm Pool (WHWP) & $\mathbf{0 . 7 6}$ & $\mathbf{0 . 4 2}$ \\
Oceanic Niño Index (ONI) & $\mathbf{0 . 5 0}$ & -0.02 \\
Multivariate ENSO Index (MEI) & $\mathbf{0 . 5 6}$ & 0.06 \\
Niño 3 (N3) & $\mathbf{0 . 6 7}$ & 0.20 \\
Interdecadal Pacific Oscillation (IPO) & $\mathbf{0 . 5 2}$ & 0.05 \\
Northern Oscillation Index (NOI) & $\mathbf{0 . 6 3}$ & $-\mathbf{0 . 3 7}$ \\
North Pacific pattern (NP) & $\mathbf{0 . 4 7}$ & -0.15 \\
Tropical Pacific SST EOF (TRP) & $\mathbf{0 . 6 3}$ & 0.19 \\
Globally Averaged Angular Momentum & $\mathbf{0 . 5 1}$ & 0.10 \\
(GIAM) & & \\
ENSO Precipitation Index (ESPI) & $\mathbf{0 . 6 2}$ & 0.16 \\
Bivariate ENSO Timeseries (BEST) & $\mathbf{0 . 7 2}$ & 0.34 \\
Pacific North American Index (PNA) & $\mathbf{0 . 4 1}$ & 0.10 \\
Eastern Asia teleconnection pattern (EA) & $\mathbf{0 . 4 2}$ & 0.31 \\
Southern Oscillation Index (SOI) & $\mathbf{0 . 5 3}$ & -0.06 \\
Pacific Decadal Oscillation (PDO) & 0.23 & -0.07 \\
Atlantic Multidecadal Oscillation (AMO) & 0.01 & 0.11 \\
\hline
\end{tabular}

All indices are monthly averaged from January to March on each year Statistically significant values $(r>0.37, p<0.01)$ are marked in bold 

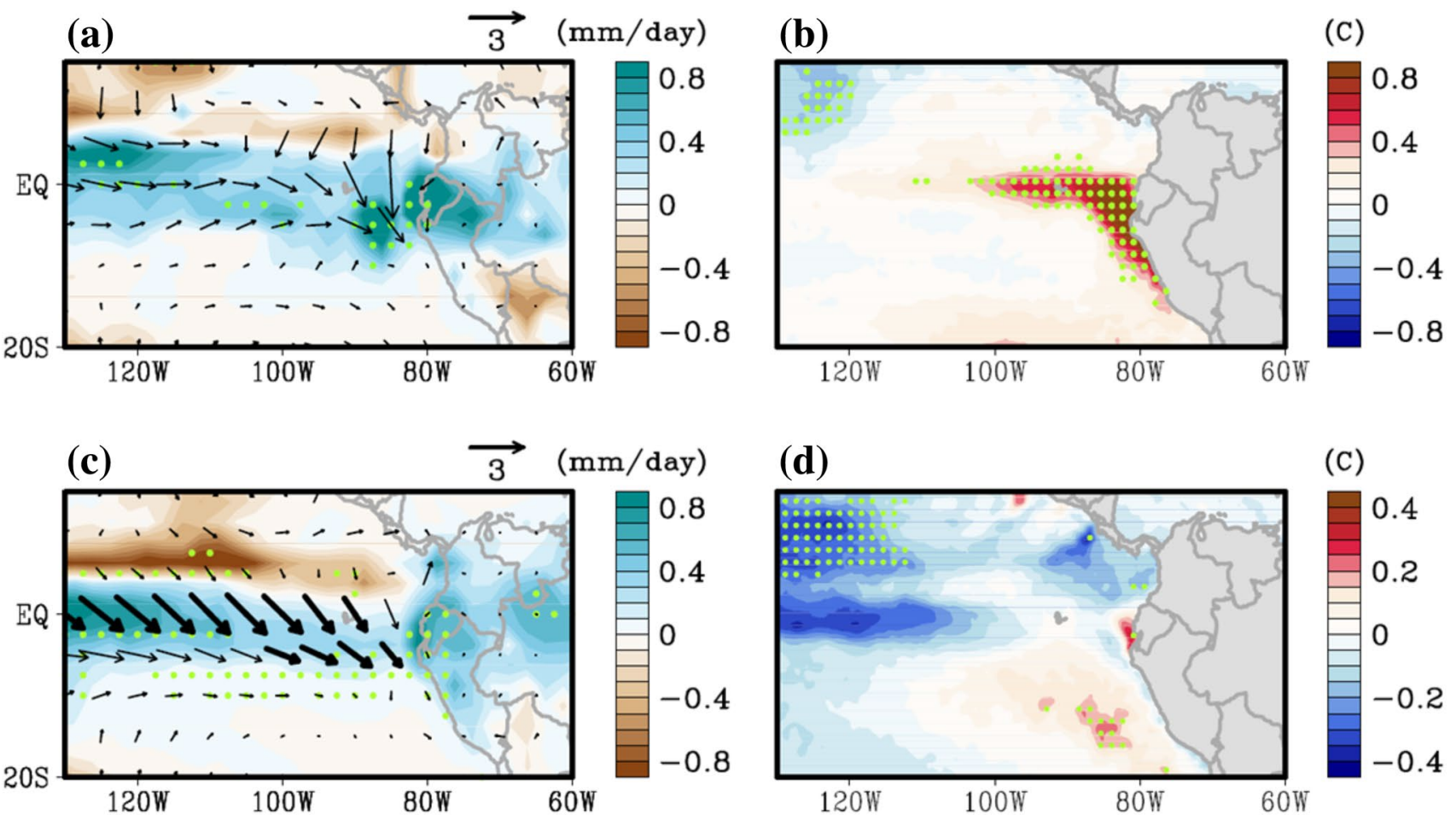

Fig. 7 Regression coefficient map of JFM anomalies based on $\mathbf{a}, \mathbf{b}$ PSST-N34 and c, d TNI index: a, c precipitation (shade, light green points are for 0.01 level significant values), winds (black vector, $\mathrm{m} / \mathrm{s}$,

anomalies in the north central Pacific than the local warming in the eastern Pacific (Fig. 7d). While previous studies have shown that the ITCZ shift can be driven by the central Pacific (CP) mode of El Niño (Yang and Magnusdottir 2016; Takahashi and Martínez 2017), we note that the CP mode was not observed in 2017. Thus, the results presented so far suggest that the flood-related wind and SST patterns are more directly linked to TNI.

\subsection{Simulations of the 2017 event}

To simulate the TNI effect on atmospheric anomalies, we conducted ECHAM5 experiments with different SST forcings (see Sect. 2.3). Compared to the control experiment (Fig. 8a1-3), the global SST forcing (Fig. 8b1-3) reasonably reconstructs the observed anomalous precipitation pattern, such as the enhanced ITCZ in the eastern Pacific and its southward shift. When considering only the EP region (Fig. 8c1-3), the model captures the increase in precipitation over the Peruvian coast. By comparison, none of the other SST forcings, including the WP, AT and WP + AT, reproduce the precipitation increase near the Peruvian coast (Fig. S3). These simulations indicate that the increased precipitation in JFM 2017 is likely caused by the anomalous SST in the eastern Pacific, which has a particularly strong effect in March. thicker arrows are for 0.01 level significant values) and b, d SST (shade, light green points are for 0.01 level significant values)

The simulated lower tropospheric winds (Fig. 9) support the importance of EP SST anomalies to the 2017 event. The northerly wind anomalies only appear in the tropical eastern Pacific in February and March with a smaller magnitude (Fig. 9a-2, a-3), which is different from the strong wind anomalies observed from January through March (Fig. 3d-f). This discrepancy becomes more pronounced in the EP, where the anomalous winds are weaker in February (Fig. 9b-2) and stronger in March (Fig. 9b-3). Given that northerly wind anomalies appeared a few months before the peak local SST (Fig. 3), the wind anomalies may positively interact with the EP SST and then self-strengthen. These features are not shown in the analysis of the other forcings (Fig. S4). This supports the role of the EP SST in enhancing the onshore wind anomalies and subsequent increase in precipitation. Putting these together, the SST anomalies over EP may be initially triggered by the weakened trade wind and subsequently intensified through the atmosphere-ocean feedback, before developing into a pattern resembling the coastal El Niño. The mechanism leading to the trade wind weakening is manifold and likely dominated by stochastic forcing. 

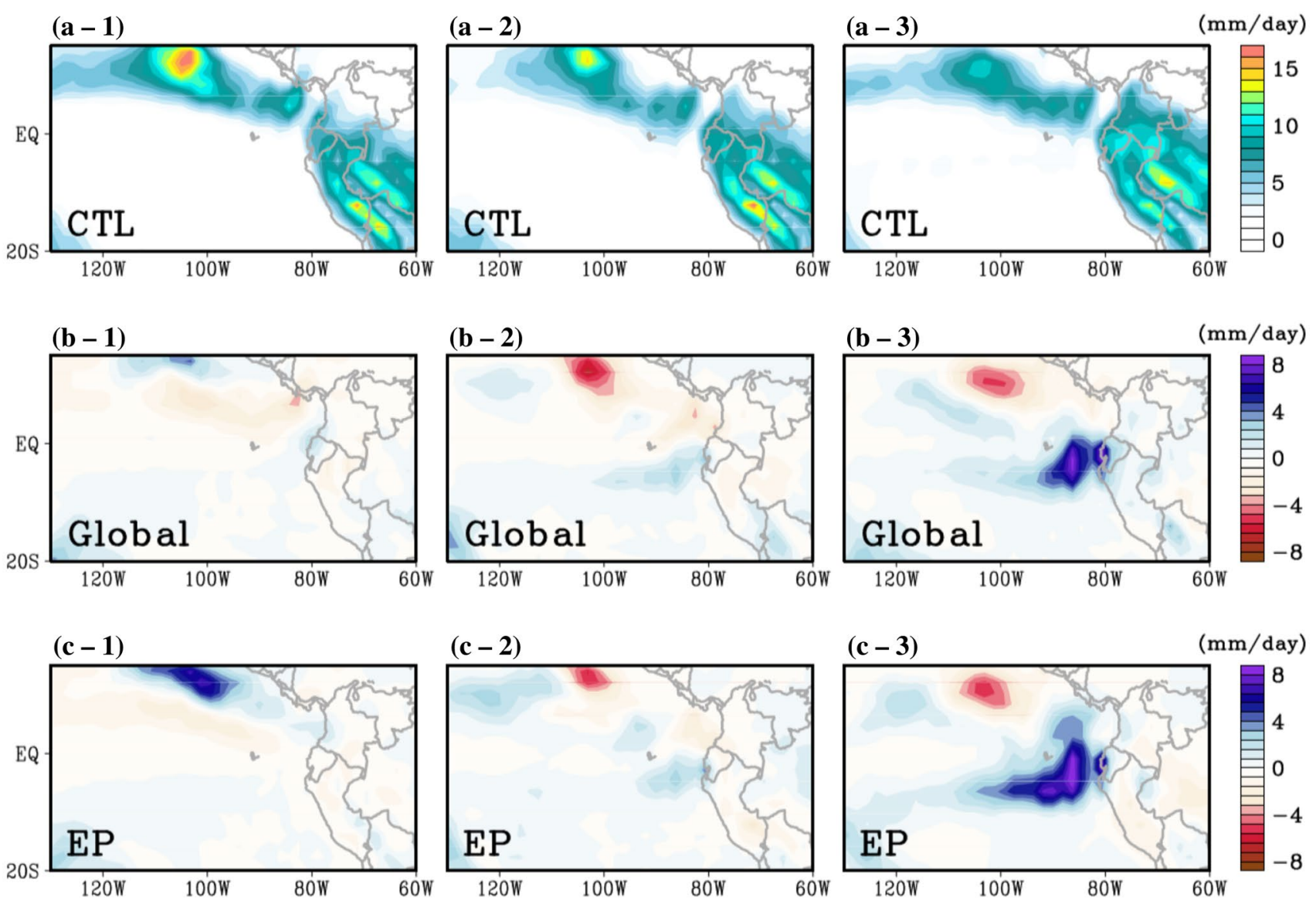

Fig. 8 Monthly averaged precipitation (mm/day) reconstructed by ECHAM5, from January to March 2017 a CTL, b Global, c EP
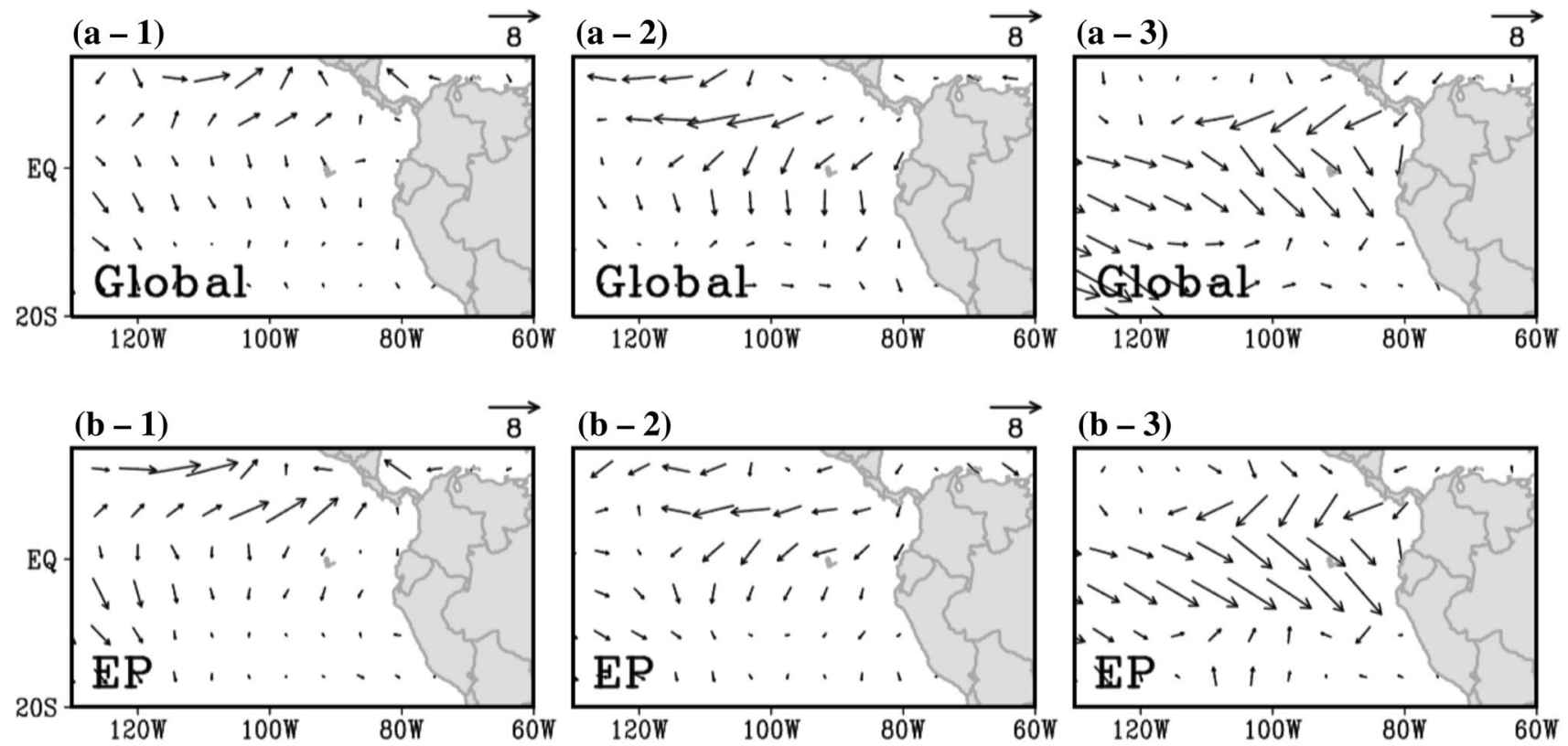

Fig. 9 Monthly anomalies of averaged Winds (surface, m/s) simulated by ECHAM5, from January to March 2017 a Global and b EP 
Fig. 10 Longitudinal average $(110 \mathrm{~W}-80 \mathrm{~W})$ of precipitation (mm/day, shade) and divergence of water vapor flux $\left(\nabla \cdot Q_{D}\right.$, contour, interval is 25$)$ subtracted by mean during JFM. In order to mask weak convergence and divergence, the limit of maximum valued is set to -10 (convergence is negative)
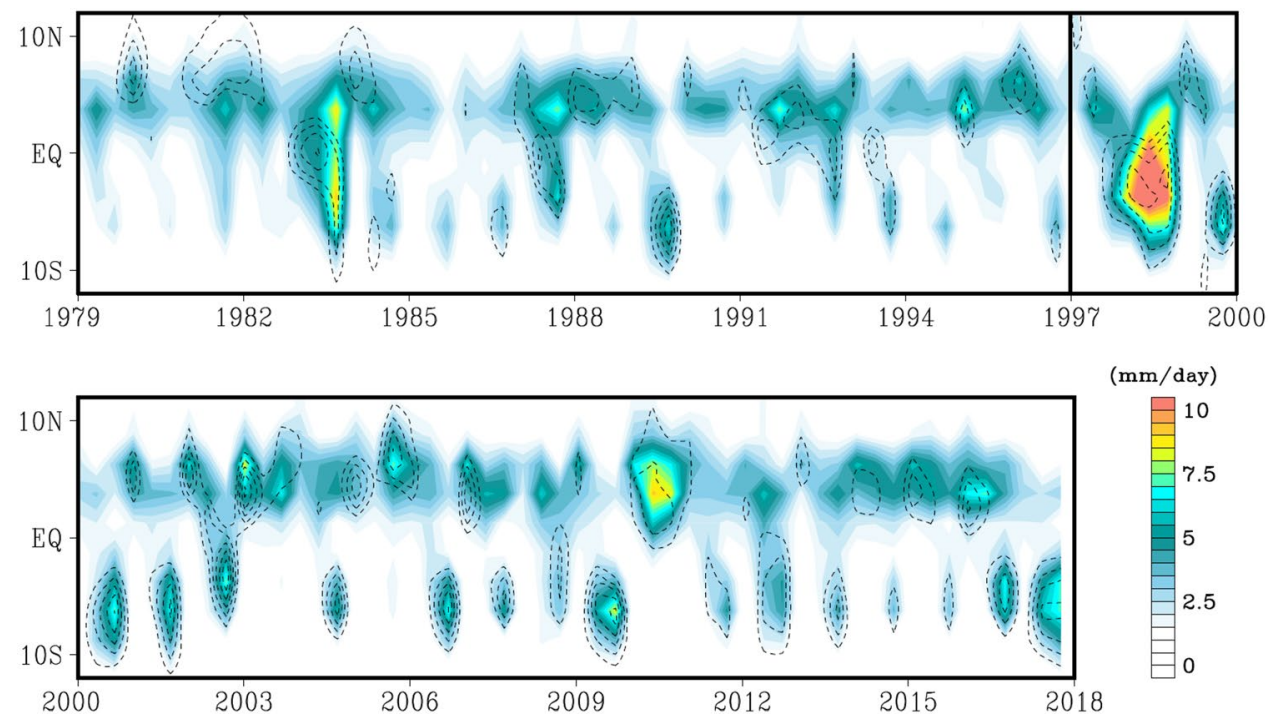

\subsection{Long-term change and implications for future projection}

Figure 10 shows the monthly precipitation and deviation of the divergence of water vapor flux $\left(\nabla \cdot \vec{Q}_{D}\right)$ averaged within the longitudes of $110 \mathrm{~W}-80 \mathrm{~W}$ for JFM from 1979 to 2017. Southward displacement of the ITCZ (hereafter "ITCZ shift") can be seen by the concurrence of precipitation and negative $\nabla \cdot \vec{Q}_{D}$ south of the equator. If the extreme 1997-1998 ENSO is excluded, the result in Fig. 10 then indicates an increase in the southward displacement of the ITCZ, particularly during the recent 18 years (2000-2017). In addition to the increasingly frequent ITCZ shift, the intensification in precipitation and $\nabla \cdot \vec{Q}_{D}$ is also evident after year 2000. This tendency raises a question whether, in the future, more excessive deluges could occur because of such an enhanced ITCZ fluctuation.

\section{Conclusions}

The catastrophic floods in Peru during January-March 2017 were accompanied by a southward-shifted ITCZ and local SST maximum. Regionally, strong northwesterly wind and positive SST anomalies developed in the eastern Pacific prior to the March flooding. Contrary to previous extreme flooding events, such as 1982-1983 and 1997-1998, the 2017 event was not induced by a strong El Niño. Instead, the localized SST warming, referred to as a 'Coastal El Niño,' was constrained around northern Peru and southern Ecuador. The early 2017 heavy precipitation may be initiated by certain changes in atmospheric circulation followed by an oceanic response, triggering enhanced convection, an inference that echoes the finding of Yu and Zhang (2018).
The common environmental features associated with heavy precipitation in Peru include the southward shift of the ITCZ, strong southerly wind anomalies, and subsequent local SST warming in northern Peru. Based on reanalysis data, vapor flux convergence and precipitation appear to have increased during the last 40 years; we did not find evidence of this trend being associated with natural variability such as the Pacific Decadal Oscillation and the Atlantic Multidecadal Oscillation. Amid the lack of resounding largescale forcing in the 2017 case, future work should focus on the linkage between heightened flood potential and largescale tropical precursors such as the TNI and Niño $1+2$.

Acknowledgements This research is funded by the National Research Foundation of Korea under Grant NRF_2017R1A2B4007480 and the the Korea Meteorological Administration Research and Development Program under Grant KMI2018- 01015. SYW is supported by US DOE Award Number DE-SC0016605 and SERDP Project Number RC19-1389.

Open Access This article is licensed under a Creative Commons Attribution 4.0 International License, which permits use, sharing, adaptation, distribution and reproduction in any medium or format, as long as you give appropriate credit to the original author(s) and the source, provide a link to the Creative Commons licence, and indicate if changes were made. The images or other third party material in this article are included in the article's Creative Commons licence, unless indicated otherwise in a credit line to the material. If material is not included in the article's Creative Commons licence and your intended use is not permitted by statutory regulation or exceeds the permitted use, you will need to obtain permission directly from the copyright holder. To view a copy of this licence, visit http://creativecommons.org/licenses/by/4.0/.

\section{References}

Adler RF, Huffman GJ, Chang A, Ferraro R, Xie P, Janowiak J, Rudolf B, Schneider U, Curtis S, Bolvin D, Gruber A, Susskind J, Arkin 
P (2003) The version 2 global precipitation climatology project (GPCP) monthly precipitation analysis (1979-Present). J Hydrometeor 4:1147-1167

Albert A, Echevin V, Lévy M, Aumont O (2010) Impact of nearshore wind stress curl on coastal circulation primary productivity in the Peru upwelling system. J Geophys Res 115:C12033. https://doi. org/10.1029/2010JC006569

Back LE, Bretherton CS (2009) On the relationship between SST gradients, boundary layer winds and convergence over tropical oceans. J. Clim 22:4182-4196. https://doi.org/10.1175/2009JCLI2392.1

Behringer D, Xue Y (2004) Evaluation of the global ocean data assimilation system at NCEP: The Pacific Ocean. In: Proc. Eighth Symp. on Integrated Observing and Assimilation Systems for Atmosphere, Oceans, and Land Surface, AMS 84th Annual Meeting, Washington State Convention and Trade Center, Seattle, Washington, 11-15 January 2004. http://ams.confex.com/ams/pdfpa pers/70720.pdf]

Chen T-C (1985) Global water vapor flux and maintenance during FGGE. Mon Weather Rev 113:1801-1819

Chen M, Xie P, et al (2008) CPC Unified Gauge-based analysis of global daily precipitation. In: Western Pacific Geophysics Meeting, Cairns, Australia, 29 July-1 August, 2008

Coelho CAS (2002) Exploring the impacts of the tropical Pacific SST on the precipitation patterns over South America during ENSO periods. Theoret Appl Climatol 71:185-197

ENFEN (Multisectorial Committee for the Study of El Niño) (2017) Technical Report, ENFEN No.1-2017. January 2017 (in Spanish)

ENFEN (Multisectorial Committee for the Study of El Niño) (2017) Official communication, ENFEN No.7-2017. 30 March 2017 (in Spanish)

ENFEN (Multisectorial Committee for the Study of El Niño) (2017) Extraordinary Technical Report No.001-2017/ENFEN-The Coastal El Niño 2017. July 2017 (in Spanish)

Garreaud RD (2018) A plausible atmospheric trigger for the 2017 coastal El Niño. Int J Climatol 38(S1):e1296-e1302. https://doi. org/10.1002/joc. 5426

Goldberg RA, Tisnado G, Scofield RA (1987) Characteristics of extreme rainfall events in Northwestern Peru during the 19821983 El Niño period. J Geophys Res 92:14225-14241

Huyer A, Smith RL, Paluszkiewicz T (1991) Coastal upwelling off Peru during normal and El Niño times. J Geophys Res 92:14297-14307

Kobayashi S, Ota Y, Harada Y, Ebita A, Moriya M, Onoda H, Onogi K, Kamahori H, Kobayashi C, Endo H, Miyaoka K, Takahashi K (2015) The JRA-55 Reanalysis: general specifications and basic characteristics. J Meteorol Soc Jpn 93:5-48. https://doi. org/10.2151/jmsj.2015-001

Lagos P, Buizer J (1992) El Nino and Peru: a nation's response to interannual climate variability. In: Majundar SK, Miller EW, Schmalz RF (eds) Natural and technological disasters: causes, effects, and preventative measures. The Pennsylvania Academy of Science, pp 223-239

Lavado-Casimiro W, Espinoza JC (2014) Impactos de El Niño y La Niña en las lluvias del Perú (1965-2007). Rev Bras Meteor 29(2):171-182

Nordeng TE (1994) Extended versions of the convective parametrization scheme at ECMWF and their impact on the mean and transient activity of the model in the tropics. European Centre for Medium-Range Weather Forecasts, Reading

Okamoto K, Iguchi T, Takahashi N, Iwanami K, Ushio T (2005) The Global Satellite Mapping of Precipitation (GSMaP) project. In: 25th IGARSS proceedings, pp 3414-3416
Peixoto JP, Oort A-H (1992) Physics of climate. American Institute of Physics, New York, p 520

Ramirez IJ, Briones F (2017) Understanding the El Nino Costero of 2017: the definition problem and challenges of climate forecasting and disaster responses. Int J Disaster Risk Sci 8:489-492. https:// doi.org/10.1007/s 13753-017-0151-8

Rayner NA, Parker DE, Horton EB, Folland CK, Alexander LV, Rowell DP, Kent EC, Kaplan A (2003) Global analyses of sea surface temperature, sea ice, and night marine air temperature since the late nineteenth century. J Geophys Res 108(D14):4407. https:// doi.org/10.1029/2002JD002670

Reynolds Richard W, Smith Thomas M, Liu Chunying, Chelton Dudley B, Casey Kenneth S, Schlax Michael G (2007) daily highresolution-blended analyses for sea surface temperature. J. Clim 20:5473-5496

Roeckner E (2003) The atmospheric general circulation model ECHAM5: Part 1: model description. Max-Planck-Institut fuer Meteorologie, Hamburg

Silva VBS, Kousky VE (2012) The South American Monsoon system: climatology and variability. In: Wang S-Y (ed) Modern climatology, InTech, Rijeka. https://doi.org/10.5772/2014

Sulca J, Takahashi K, Espinoza JC, Vuille M, Lavado Casimiro W (2017) Impacts of different ENSO flavors and tropical Pacific convection variability (ITCZ, SPCZ) on austral summer rainfall in South America, with a focus on Peru. Int J Climatol. https:// doi.org/10.1002/joc.5185

Takahashi K (2004) The atmospheric circulation associated with extreme rainfall events in Piura, Peru, during the 1997-1998 and 2002 El Niño events. Ann Geophys 22:3917-3926

Takahashi K, Martínez AG (2017) The very strong coastal El Niño in 1925 in the far-eastern Pacific. Clim Dyn. https://doi.org/10.1007/ s00382-017-3702-1

Tiedtke M (1989) A comprehensive mass flux scheme for cumulus parameterization in large-scale models. Mon Weather Rev 117(8):1779-1800

Trenberth KE, Stepaniak DP (2001) Indices of El Niño evolution. J Clim 14:1697-1701

Trenberth KE, Dai A, Rasmussen RM, Parsons DB (2003) The changing character of precipitation. Bull Am Meteorol Soc 84:1205-1217

Woodman R (1999) Modelo estadístico de pronóstico de las precipitaciones en la costa norte del Perú. El Fenómeno El Niño. In: Investigación para una prognosis, 1er encuentro de Universidades del Pacífico Sur: Memoria 93-108, Piura-Perú

Yang W, Magnusdottir G (2016) Interannual signature in daily ITCZ states in the east Pacific in boreal spring. J Clim 29:8013-8025. https://doi.org/10.1175/JCLI-D-16-0395.1

Yu HY, Zhang MH (2018) Explaining the year-to-year variability of the eastern Pacific intertropical convergence zone in the boreal spring. J Geophys Res Atmos. https://doi.org/10.1002/2017JD028156 (in press)

Publisher's Note Springer Nature remains neutral with regard to jurisdictional claims in published maps and institutional affiliations. 